Please do not remove this page

RMIT

UNIVERSITY

\title{
Migration Pathways for Frontline Care Workers in Australia and New Zealand: Front Doors, Side Doors, Back Doors and Trapdoors
}

Howe, Joanna; Charlesworth, Sara; Brennan, Deborah

https://researchrepository.rmit.edu.au/esploro/outputs/9921863569801341/filesAndLinks?institution=61RMIT_INST\&index=null

Howe, J., Charlesworth, S., \& Brennan, D. (2019). Migration Pathways for Frontline Care Workers in Australia and New Zealand: Front Doors, Side Doors, Back Doors and Trapdoors. University of New South Wales Law Journal, 42(1), 211-241.

https://researchrepository.rmit.edu.au/discovery/fulldisplay/alma9921863569801341/61RMIT_INST:Resea rchRepository

Document Version: Published Version 


\title{
MIGRATION PATHWAYS FOR FRONTLINE CARE WORKERS IN AUSTRALIA AND NEW ZEALAND: FRONT DOORS, SIDE DOORS, BACK DOORS AND TRAPDOORS
}

\author{
JOANNA HOWE, ${ }^{*}$ SARA CHARLESWORTH ${ }^{* *}$ AND DEBORAH BRENNAN ${ }^{* * *}$
}

\begin{abstract}
This article examines the use of migration law and policy to address the labour needs of the care sector in two jurisdictions. New Zealand uses an Essential Skills visa to allow the direct entry of care workers on a temporary basis while Australia relies on a range of overseas born entrants including international students and working holiday makers, to meet labour supply challenges in the care sector and to supplement the local workforce, which includes many long-term permanent migrants. Changes to the work rights of working holiday makers, together with the introduction of a Designated Area Migration Agreement for Northern Australia and a Pacific Labour Scheme have created new opportunities for temporary entrants to work in care occupations but there is pressure on the Australian Government to open a dedicated temporary labour migration pathway for care workers. New Zealand's revolving door of temporary migrant care workers and Australia's de facto low skilled migration pathway both present regulatory challenges with regard to the protection of these workers in the labour market, their claims to citizenship and their opportunity to realise the 'triple win' promised in the temporary labour migration literature. The increasing reliance by Australia and New Zealand on temporary migrant care workers to meet the labour supply challenges in the sector also masks a range of other endemic employment relations problems in the sector (in particular, low pay) and may lead to a permanent demand for temporary migrant workers at the expense of local care workers.
\end{abstract}

\section{INTRODUCTION}

As demand for care services rises across the globe, governments in many high income countries are opting to promote markets in care, providing subsidies to consumers so that they can purchase services for themselves, rather than funding

\footnotetext{
* Associate Professor of Law at the University of Adelaide and a Consultant with Harmers Workplace Lawyers.

** Professor of Work, Gender \& Regulation at the School of Management, RMIT University.

*** Emeritus Professor at the Social Policy Research Centre, UNSW Sydney.
} 
services directly. In parts of Europe, North America, East Asia and the Gulf states, the shortage of care services and local care workers has been addressed by large inflows of immigrant workers, mainly women, who are willing to do work that is poorly paid and often seen as low-skilled. The migration of care workers from poor to rich countries is so extensive and entrenched that it has been described as a 'distinguishing characteristic of the world economy of the late twentieth and early twenty-first centuries'. ${ }^{1}$ It has given rise not only to the 'globalization of care work' 2 but also to a new, gendered 'international division of reproductive labour' that raises complex regulatory and political challenges. ${ }^{3}$

While many countries allow or even encourage the migration of care workers, Australia and New Zealand have taken distinctive approaches to determining how labour supply challenges are met in the care sector. These two countries have been selected as the focus for this comparative study for two reasons. Despite the relatively large share of migrants in their care sectors, neither country has been the focus of the in-depth scholarly attention paid to migrant care workers in Europe and North America. Further, these two jurisdictions have many of their legal fundamentals in common. Legal origins theory recognises that Australia and New Zealand are from the same legal family, with both adopting the United Kingdom's ('UK') common law system and Westminster political system. ${ }^{4}$ Both are social democracies and have a common economic system. These characteristics suggest that labour migration policy in relation to frontline care workers in Australia and New Zealand share similar foundations.

New Zealand uses a specific temporary work visa to facilitate the temporary entry of care workers, ${ }^{5}$ whereas Australia has historically eschewed specific visa pathways permitting 'low-skilled' temporary labour migration ${ }^{6}$ providing a limited temporary migration pathway restricted to care occupations designated as 'highskill' through its temporary skilled migration visa program. ${ }^{7}$ Australia has

1 Katharine M Donato and Donna Gabaccia, Gender and International Migration (Russell Sage Foundation, 2015) 114.

2 Joya Misra, Jonathan Woodring and Sabine N Merz, 'The Globalization of Care Work: Neoliberal Economic Restructuring and Migration Policy' (2006) 3 Globalizations 317, 317.

3 Fiona Williams, 'Migration and Care: Themes, Concepts and Challenges' (2010) 9 Social Policy \& Society 385, 385. See also Rhacel Salazar Parreñas, Servants of Globalization: Women, Migration, and Domestic Work (Stanford University Press, 2001) 61.

$4 \quad$ Rafael La Porta et al, 'Legal Determinants of External Finance' (1997) 52 Journal of Finance 1131; Rafael La Porta et al, 'Law and Finance' (1998) 106 Journal of Political Economy 1113; Rafael La Porta, Florencio Lopez-de-Silanes and Andrei Shleifer, 'Corporate Ownership around the World' (1999) 54 Journal of Finance 471.

5 The Essential Skills Work Visa category is for overseas workers who have a job offer for a job on the Essential Skills in Demand list from a New Zealand employer, who can demonstrate the worker is suitable to do the job and that other New Zealanders are not available. See New Zealand Immigration, About this Visa: Essential Skills Work Visa (2018) <https://www.immigration.govt.nz/new-zealandvisas/apply-for-a-visa/about-visa/essential-skills-work-visa>.

6 Deborah Brennan et al, 'Out of Kilter: Changing Care, Migration and Employment Regimes in Australia' in Sonya Michel and Ito Peng (eds), Gender, Migration, and the Work of Care: A Multi-Scalar Approach to the Pacific Rim (Palgrave Macmillan, 2017) 143, 161.

7 The Temporary Work (Skilled) (subclass 457) visa is designed to enable employers to address labour shortages by bringing in genuinely skilled workers where they cannot find an appropriately skilled 
primarily relied on many long-term and more recently arrived permanent migrants who work as 'frontline' care workers, that is, those who work in non-professional direct care jobs. ${ }^{8}$ While adequate data are not collected on the occupations held by temporary migrants in work designated as 'low-skilled', ${ }^{9}$ in Australia it would appear that care sector employers draw on a mix of temporary migrants on partner visas, international students and working holiday makers to meet labour supply challenges in the care sector. ${ }^{10}$

There is mounting pressure by employers and other interest groups on the Australian Government to increase access to migrant care workers. ${ }^{11}$ Recent reforms such as the introduction of a Designated Area Migration Agreement ('DAMA') for the Northern Territory, ${ }^{12}$ the Pacific Microstates pilot, ${ }^{13}$ and changes to the work rights of working holiday makers ${ }^{14}$ provide new opportunities for temporary migrants to come to Australia and work in the child care, aged care and disability care sectors. These schemes increase the availability of migrant care workers in Northern Australia. This has occurred without the introduction of a national, dedicated 'low-skilled' labour migration pathway akin to New Zealand's Essential Skills Visa.

Australian for jobs in eligible occupations. See Harriet Spinks, 'The Temporary Work (Skilled) (subclass 457) Visa: A Quick Guide’ (Research Paper, Parliamentary Library, Parliament of Australia, 2016).

8

For example, analysis of 2011 Census data indicates that of personal care assistants born outside Australia, just over half (51 per cent) arrived in Australia before 2001: Somayeh Parvazian and Sara Charlesworth, 'A Profile of Frontline Care Workers in Australia: Personal Care Assistants' (Working Paper No 2, Centre for Work + Life, University of South Australia, June 2014) 8.

9 Detailed occupational data is available only for 'skilled' visa holders by the Department of Immigration and Border Protection ('DIBP'). However, analysis by the authors of the Australian Bureau of Statistics 2016 Characteristics of Recent Australian Migrants Survey suggests that of the migrants working in frontline care occupations who had arrived in Australia since 2006, 64 per cent arrived on a temporary visa. However, in 2016 only 36 per cent still held a temporary visa: Australian Bureau of Statistics, 'Characteristics of Recent Migrants, November 2016' (Catalogue No 6250.0, 14 June 2017) $<$ http://www.abs.gov.au/ausstats/abs@.nsf/mf/6250.0>.

10 However, in a recent trial data matching exercise with 2011 Census data and the DIBP's administrative data on temporary student and skilled visa holders, the Australian Bureau of Statistics identified that for employed primary visa holder students, the low-skilled care occupation of personal carers and assistants was the sixth most frequently reported occupation. See Australian Bureau of Statistics, 'Assessing the Quality of Linking Temporary Visa Holders Administrative Data to the 2011 Census' (Research Paper No 1351.0.55.061, National Migrant Statistics Unit, 20 March 2017) 38.

11 See Elizabeth Adamson et al, 'Social Care and Migration Policy in Australia: Emerging Intersections?' (2017) 52 Australian Journal of Social Issues 78, 88-90.

12 Department of Immigration and Border Protection, 'Designated Area Migration Agreements' (Report, December 2015).

13 The Pacific Microstates - Northern Australia Worker Pilot Program is a 2016 extension of the Seasonal Worker Programme and includes 250 places for workers from Pacific Microstates to work in designated low-skilled occupations in Northern Australia, including in care occupations. See Quintina Naime, Pacific Countries to Benefit More from Seasonal Workers Program (4 March 2016) Loop $<$ http://www.looppng.com/content/pacific-countries-benefit-more-seasonal-workers-program>. In September 2017 the federal government introduced a new Pacific Labour Scheme which provides 2000 places for workers from the Pacific Microstates to come to Australia to work in low-skilled occupations for up to three years.

14 For example for au pairs who live in private homes to care for children. See Department of Immigration and Border Protection, 'Request Permission to Work with an Employer Beyond 6 Months on a Working Holiday or Work and Holiday Visa' (Form 1445, Commonwealth of Australia, 2015) $<$ https://immi.homeaffairs.gov.au/form-listing/forms/1445.pdf $>$. 
Despite increasing international attention to the role of migration regulation in shaping migrants' pathways into care work and their working conditions,${ }^{15}$ little analysis has been done of how shifts in the migration regimes of Australia and New Zealand influence the migration of frontline care workers. This lack of attention is surprising because, as highlighted below, in both countries a significant proportion of the frontline care workforce is overseas born. As a basis for better understanding the role of migration in care work, this article examines how migration law and policy are used in these two jurisdictions to address the labour needs of the care sector. Our analysis is informed by social science scholarship, focused first on the interaction of employment, care and migration regimes with their complex interplay of institutions, policies, national and global conditions that produce the conditions of work for care workers, ${ }^{16}$ and secondly on the gendered construction of skill. ${ }^{17}$ The social and gendered construction of skill ${ }^{18}$ is a central underpinning to scholarship on migrant workers, ${ }^{19}$ especially in frontline care work..$^{20}$

Skill is an important analytical category that lies at the intersection of gender and migration, powerfully shaping the mobility of labour. ${ }^{21}$ For example, the fact that nursing qualifications from the Philippines are not recognised as equivalent to those gained in Australia or New Zealand means a Filipina migrant nurse cannot access skilled migration pathways in either country and cannot work as a nurse if she migrates through other pathways. Perceptions and definitions of skill underpin the 'gender responsiveness' of migration regimes in ways that are pertinent to our analysis of the migration pathways of frontline care workers. ${ }^{22}$ The designation of occupations as 'skilled' or 'unskilled' in migration regulation draws on gendered understandings of work, reflecting not only the historical skills definitions in

15 International Labour Office, 'Fair Migration: Setting an ILO Agenda' (Report of the Director-General No I(B), June 2014); Joanna Howe and Rosemary Owens (eds), Temporary Labour Migration in the Global Era: The Regulatory Challenges (Hart Publishing, 2016); Cathryn Costello and Mark Freedland (eds), Migrants at Work: Immigration and Vulnerability in Labour Law (Oxford University Press, 2014).

16 Fiona Williams, 'Converging Variations in Migrant Care Work in Europe' (2012) 22 Journal of European Social Policy 363; Annamaria Simonazzi, 'Care Regimes and National Employment Models' (2009) 33 Cambridge Journal of Economics 211; Franca van Hooren, 'Varieties of Migrant Care Work: Comparing Patterns of Migrant Labour in Social Care' (2012) 22 Journal of European Social Policy 133.

17 See, eg, Pat Armstrong, 'Skills for Care' in Pat Armstrong and Susan Braedley (eds), Troubling Care: Critical Perspectives on Research and Practices (Canadian Scholars Press, 2013) 101.

18 See Rosemary Hunter, The Beauty Therapist, the Mechanic, the Geoscientist and the Librarian: Addressing Undervaluation of Women's Work (ATN WEXDEV, 2000).

19 Martin Ruhs and Bridget Anderson (eds), Who Needs Migrant Workers? Labour Shortages, Immigration, and Public Policy (Oxford University Press, 2010); Anna Boucher, ‘Australia’s De Facto Low Skilled Migration Programs' in Committee for Economic Development of Australia, 'Migration: The Economic Debate' (Research Report, November 2016) 43

$<$ https://www.ceda.com.au/CEDA/media/ResearchCatalogueDocuments/Research\%20and\%20Policy/PD F/32509-CEDAMigrationReportNovember2016Final.pdf $>$.

20 Pat Armstrong, Hugh Armstrong and Krista Scott-Dixon, Critical to Care: The Invisible Women in Health Services (University of Toronto Press, 2008) 92-6; Elyane Palmer and Joan Eveline, 'Sustaining Low Pay in Aged Care Work' (2012) 19 Gender, Work and Organization 254.

21 Eleonore Kofman and Parvati Raghuram, Gendered Migrations and Global Social Reproduction (Palgrave MacMillan, 2015) 102.

22 See Anna Boucher, Gender, Migration and the Global Race for Talent (Manchester University Press, 2016); Boucher, 'Australia’s De Facto Low Skilled Migration Programs', above n 19. 
employment regulation, but also a gender biased undervaluing of the 'soft skills' employed by a wide range of workers. ${ }^{23}$ It is on the basis of such skills definitions that migration regulation opens or closes doors to migrants and imposes conditions on entry and migration status. This has a particular impact on allowing the migration of those who want to work in frontline care jobs as well as on migrant frontline care workers, whose work is devalued because of its similarity to the unpaid care work performed by women, which is perceived to be 'low-skilled' or even 'unskilled'. ${ }^{24}$ As Armstrong, Armstrong and Scott-Dixon argue 'skill' is equated with the education level set as a job requirement so that skill is about the job rather than the individual holding the job, thus equating the skills of the work with the skills of the worker. ${ }^{25}$

The gendering of what constitutes skill in migration regimes intersects directly with the gendered undervaluation of frontline care work in both the Australian and New Zealand contexts where labour migration pathways are devised according to designated occupational skill levels with different conditions for visas depending on the skill classification of the visa holder's application. The basis for these skill designations in both countries is the Australian and New Zealand Standard Classification of Occupations ('ANZSCO'), which classifies occupations by the skill level required to perform the tasks of each occupation. Frontline care workers are classified as requiring only ANZSCO Level 4 skills. ${ }^{26}$ This is the second lowest skill level in a five-level skill hierarchy. ${ }^{27}$ Nurses, teachers and administrators in the care sector are classified at a higher level. However, as Armstrong, Armstrong and Scott-Dixon suggest above, such skill levels may not reflect the skills demanded in practice for a particular care job.

In this article, 'migrant care worker' refers to those born outside the country in which they are employed in frontline care work. Our focus is on nonprofessional workers in childcare and aged care - highly feminised occupations, ${ }^{28}$ classified in both Australia and New Zealand at ANZSCO Level 4. Data on the

23 Boucher, Gender, Migration and the Global Race for Talent, above n 22, $26-7$.

24 See Nancy Folbre, Greed, Lust \& Gender: A History of Economic Ideas (Oxford University Press, 2009); Pat Armstrong and Susan Braedley (eds), Troubling Care: Critical Perspectives on Research and

Practices (Canadian Scholars Press, 2013).

25 Armstrong, Armstrong and Scott-Dixon, above n 20, 92.

26 The five skill levels in ANZSCO are defined in terms of formal education and training, previous experience and on-the-job training. See Australian Bureau of Statistics, 'ANZSCO - Australian and New Zealand Standard Classification of Occupations' (Catalogue No 1220.0, 26 June 2013)

$<$ http://www.abs.gov.au/AUSSTATS/abs@.nsf/DetailsPage/1220.02013,\%20Version\%201.2?OpenDocu ment>.

27 Occupations in ANZSCO Skill Level 4 are defined as having: a level of skill commensurate with one of the following:

- $\quad$ NZ Register Level 2 or 3 qualification or

- $\quad \mathrm{AQF}$ Certificate II or III.

At least one year of relevant experience may substitute for the formal qualifications listed above. In some instances relevant experience may be required in addition to the formal qualification.

See Australian Bureau of Statistics, 'ANZSCO - Australian and New Zealand Standard Classification of Occupations' (Information Paper No 1221.0, 28 September 2005)

$<$ http://www.abs.gov.au/ausstats/abs@.nsf/Previousproducts/C4BECE1704987586CA257089001A918>.

In Australia, for example, in 2011, 96 per cent of child carers were female as were 82 per cent aged an disabled carers and 87 per cent personal care assistants. See Elizabeth Adamson et al, above n 11, 80 . 
proportions of migrant workers in the specific frontline occupations in care work in Australia and New Zealand can be gleaned through published census data and/or specific sub-sector studies. In Australia in 2011, 27 per cent of 'childcarers' were born overseas; 34 per cent of 'aged and disabled carers' (mainly home care workers) were born overseas; and 44 per cent of 'personal care assistants' (mainly residential aged care workers) were born overseas. ${ }^{29}$ Statistics New Zealand provides published census data in the main by ethnicity rather than country of birth. However, a study of unpublished New Zealand census data indicates that in 2013 in the aged care sector 31 per cent of caregivers to the elderly (home care and residential care workers) were born overseas. ${ }^{30}$

This article is structured in three parts. First, in this introduction we contextualise and frame the context in which care worker migration occurs in both Australia and New Zealand. Second, we map the current pathways for migrant care workers in both jurisdictions and analyse the construction of these pathways. Third, we consider and assess these pathways from the perspective of their ability to meet the needs of migrant care workers, local care workers and employers.

We argue that in both Australia and New Zealand migration pathways for care workers are vexed and contingent, producing precarity for workers and embedding low wages and conditions in the care sectors in these countries. We draw upon the motif of a series of 'doors' to identify the type and conditions associated with each entry pathway. ${ }^{31}$ This motif of doors exposes how immigration control and selection in Australia and New Zealand has been underpinned by a gendered construction of skill. This has significantly disadvantaged frontline care workers from accessing the benefits and protections provided by front door migration pathways. Migrant care workers can enter New Zealand through a 'front door', with the Essential Skills Work Visa providing a direct labour migration pathway, although unlike other workers on this visa who are deemed to be of a higher skill, frontline care workers have no direct pathway to permanent residency. In Australia, the 'front door' is firmly closed to frontline care workers, with formal policy insisting that Australia's labour migration program is solely for skilled workers. ${ }^{32}$ Nonetheless, there are 'side doors' into Australia. Migrant care workers

29 Australian Bureau of Statistics, 'Census 2011' (2011), data on personal care assistants provided by the Australian Bureau of Statistics on request as customer report only. See also Elizabeth Adamson et al, above n 11,80 .

30 Paul Callister, Robert Didham and Juthika Badkar, 'Ageing New Zealand: The Growing Reliance on Migrant Caregivers, a 2014 Update’ (Working Paper, Callister \& Associates, December 2014) 8.

31 Aristide R Zolberg, 'The Next Waves: Migration Theory for a Changing World' (1989) 23 International Migration Review 403; Andrew Geddes, 'Migration and the Welfare State in Europe' (2003) 74 Political Quarterly 150; Chris F Wright and Stephen Clibborn, 'Back Door, Side Door or Front Door? An Emerging De-Facto Low-Skilled Immigration Policy in Australia' (2017) 39 Comparative Labor Law and Policy Journal 165.

32 In recent years, many scholars have countered that the temporary skilled migration program has become a general labour supply visa: see Joanna Howe, 'Is the Net Cast Too Wide? An Assessment of whether the Regulatory Design of the 457 Visa Meets Australia's Skill Needs' (2013) 41 Federal Law Review 443, 453. Other pathways, such as the Working Holiday Maker program and international student visas, have created a de facto low-skilled labour migration program: see Joanna Howe and Alexander Reilly, 'Meeting Australia's Labour Needs: The Case for a New Low-Skill Work Visa' (2015) 43 Federal Law Review 259; Boucher, ‘Australia’s De Facto Low Skilled Migration Programs', above n 19. 
are allowed entry into the Australian labour market via agreements between Home Affairs and specific employers, and in Northern Australia through a variety of mechanisms. We categorise these arrangements as 'side doors' because they require a labour agreement to be made before visas can be granted to migrant workers. This process requires a considerable degree of time and resources as an employer or industry must mount a persuasive, evidence-based case for the need for such an agreement. This can be distinguished from the 'front door' pathway which allows migrant workers and their employers to directly apply for an existing visa category according to a streamlined process. In both Australia and New Zealand, international students and backpackers who enter on visas ostensibly for a non-work purpose, are often used to meet labour market needs. We characterise these pathways as 'back doors' because although these visas allow for the performance of work, they are not created for that purpose and sit outside each country's formal labour migration program. ${ }^{33}$ These different pathways coalesce to produce what we call a 'trapdoor', as each of the aforementioned migration pathways ensnare frontline care workers into permanently temporary status with no straightforward pathway to permanent residency. The gendering of what constitutes skill in migration regimes intersects directly with the gendered undervaluation of frontline care work. The end result in both countries is a care sector that increasingly relies on an inadequately protected and acutely vulnerable temporary migrant workforce.

\section{THE EVOLUTION OF MIGRATION PATHWAYS FOR CARE WORKERS}

\section{A New Zealand}

In the last decade of the $20^{\text {th }}$ century, New Zealand's immigration policy transformed from its broad 'nation-building' approach into being anchored in achieving economic objectives. This metamorphosis was pivotal to the development of a designated 'low-skilled' labour migration pathway that facilitated the entry of frontline migrant care workers.

33 This is a different categorisation of visas for international students and backpackers to that given by employment relations scholars Chris F Wright and Stephen Clibborn who designate these visas as being a 'side door' arrangement on the basis that these schemes exist outside the formal scope of Australia's labour migration program. They categorise undocumented migrant workers as comprising those permitted through a 'back door'. We have chosen to categorise labour agreement pathways as part of a 'side door' because they require far greater time and resources in facilitating labour migration, and are thus distinguishable from the 'front door' provided by visa categories for work of certain skill. We also think 'back doors' is a more apt motif for visas for a non-work purpose as these sit outside the formal scope of Australia's labour migration program. We exclude undocumented workers in our motif of doors as the official policy of the Australian state is to not permit undocumented migrant work and to deport this set of workers if identified. For an alternative categorisation see Wright and Clibborn, above n 31 . Tham et al refer to visas for work and non-work purposes as dedicated and de facto labour migration programs respectively, see Joo-Cheong Tham, Iain Campbell and Martina Boese, 'Why is Labour Protection for Temporary Migrant Workers So Fraught?: A Perspective from Australia' in Joanna Howe and Rosemary Owens (eds), Temporary Labour Migration in the Global Era: The Regulatory Challenges (Hart Publishing, 2016) 173. 


\section{Front Door}

By the early 1990s, New Zealand shifted its migration policy to give priority to the skills, employment and educational background of applicants. This upended its previous anachronistic approach that gave precedence to applicants from Anglo-Saxon countries. ${ }^{34}$ By the early 2000s, there were strong concerns over New Zealand's ability to meet skill shortages in its workforce, leading to the introduction of a new 'Skilled Migrant Category' ('SMC'). This new category for temporary skilled migration gave extra weight to applications from those who had a job offer in an identified growth area or an area of absolute skill shortage, or who had relevant work experience in New Zealand. ${ }^{35}$ In addition to professional occupations, the SMC included a wide range of trade qualifications but notably, did not include frontline care occupations. The introduction of the SMC was a significant departure from previous policy and was seen as 'testimony to the intensifying demand for labour with a wide range of skills in the New Zealand economy'. ${ }^{36}$ The introduction of the SMC occurred alongside the development of another new skilled temporary migration program, the 'work to residence' permit system. ${ }^{37}$ This began a deliberate state policy of transitioning temporary skilled migrants into permanent migrants via a two-stage process through either the SMC or the work to residence permit. As leading New Zealand demographer, Richard Bedford, noted:

Good employment and settlement outcomes for both the migrants and the host society are critical determinants of the success of contemporary immigration policy, and the work to residence transition provides one very effective route to building the experience and capability required to achieve these outcomes. ${ }^{38}$

Although New Zealand's approach to immigration policy continues to evolve, it has broadly continued to ensure that the entry of both temporary and permanent migrants meets the country's economic needs and that skilled temporary migrants are provided with a streamlined pathway to permanent residency. This transition from temporary skilled work to permanency is designed to ensure the ongoing stability and skill base of New Zealand's workforce and has become an established feature of the immigration program. In this way, the architectural foundations of New Zealand's temporary labour migration program continue to have far-reaching implications for the configuration of its national populations as well as the workings of its labour market.

It is conspicuous that the SMC does not provide a direct pathway to permanent residence for all temporary migrant workers and excludes frontline care workers who are deemed as being of lower skill. Since the 1990s, the only labour migration pathway for care workers perceived to be 'low-skilled' has been through the

34 Andrew Trlin, Paul Spoonley and Richard Bedford (eds), New Zealand and International Migration: A Digest and Bibliography, Number 5 (Massey University, Volume 5, 2010) vi-vii.

35 Ibid 8

36 Ibid 9

37 Paul Merwood, 'From Work to Residence: An Evaluation of Work Policies that Provide a Pathway to Permanent Residence in New Zealand' (2006) Labour, Employment and Work in New Zealand 142.

38 Richard Bedford, 'Skilled Migration in and out of New Zealand: Immigrants, Workers, Students and Emigrants' in Bob Birrell, Lesleyanne Hawthorne and Sue Richardson, 'Evaluation of the General Skilled Migration Categories’ (Report, Commonwealth of Australia, 2006) 224, 244. 
temporary program. There is no route to permanent residency through the SMC unless an applicant can apply under an occupational category with a higher skill level. In 2008, the launching of the Essential Skills Policy ('ESP') expressed the recognition by policy makers that labour shortages existed across a broader skill spectrum and created a new framework for frontline care workers to migrate to New Zealand for temporary work. ${ }^{39}$

Before we examine the content of this policy framework, it is important to allude briefly to the significance of the Essential Skills Policy in bringing in frontline care workers to New Zealand. The numbers of care workers with visas issued through the Essential Skills Policy have steadily increased over time. In 2010-11, visas issued through the major occupation group 'Community and Personal Service Workers' accounted for 3 per cent of the Essential Skills Policy, ${ }^{40}$ but by 2014-15, this group accounted for 11 per cent of the temporary labour migration program.$^{41}$ In this same time period, 2537 visas were issued through the Essential Skills Policy for 'aged and disability carers', 1122 for 'personal care assistants' and 400 for 'nursing support workers', resulting in a total of 4059 or 20 per cent of all ANZSCO Skill Level 4 jobs. ${ }^{42}$ The top three countries of origin for care workers during this period were the Philippines (46 per cent), Fiji (17 per cent) and India ( 13 per cent). ${ }^{43}$

Visas issued under the Essential Skills Policy are labour market tested, ${ }^{44}$ and visa conditions vary according to the skill level of the occupation. ${ }^{45}$ The Essential Skills Policy relies on the ANZSCO skill classification, which, as noted above, classifies occupations by the skill level required to perform the tasks of each occupation. ANZSCO Skill Level 1 occupations allow for a five-year visa term and ANZSCO Skill Level 2 and 3 occupations permit a three-year visa, both of which offer pathways to permanent residency for visa holders. By contrast, if the work visa is based on an offer of employment for ANZSCO Skill Level 4 or 5, the duration of the visa is 12 months. At its expiration, the employer must test the labour market before being able to renew the visa for another year. Thus, although migrant care workers have a front door labour migration pathway to New Zealand

39 International Migration Settlement \& Employment Dynamics Research, 'Migration Trends \& Outlook: 2007/08' (Report, Department of Labour, 2009) 16

$<$ http://thehub.superu.govt.nz/assets/documents/Migration\%20Trends\%20and\%20Outlook\%20200708.pdf $>$.

40 In that year the Essential Skills Policy included 22341 approved visas in total: see Ministry of Business, Innovation \& Employment, 'Migration Trends and Outlook: 2014/2015' (Annual Report, New Zealand Government, November 2015) $22<$ http://www.mbie.govt.nz/publications-research/research/migrants--monitoring/migration-trends-and-outlook-2014-15.pdf >; Callister, Didham and Badkar, above n 30.

41 Ministry of Business, Innovation \& Employment, 'Migration Trends and Outlook 2014/2015', above n 40, 24. In that year, the ESP included 28548 approved visas in total.

42 Richard Curtain, 'Aged \& Disability Caregivers: The Case for Sourcing Qualified Carers from the Pacific' (Paper presented at the New Research on Pacific Labour Mobility Workshop, Crawford School of Public Policy, ANU, 2 June 2016) 6. Ibid.

44 Immigration New Zealand, 'Amendments to the Immigration New Zealand Operational Manual' (Manual Amendments, 7 April 2016) < https://www.immigration.govt.nz/documents/amendmentcirculars/amendment-circular-2016-03.pdf>. Ibid. 
through the Essential Skills Policy, the designation of their work as ANZSCO Skill Level 4, means that they have little security beyond the 12 months of their initial contract.

The regulatory design of the Essential Skills visas for care workers creates a 'trapdoor' by channelling frontline care workers into permanently temporary status with no straightforward pathway to permanent residency. Skills visas for care work classified as ANZSCO Level 4 expire after 12 months and require labour market testing prior to renewal. Visas issued under the Essential Skills Policy can be renewed an indefinite number of times. The Organisation for Economic Cooperation and Development ('OECD') has observed that 'it is indeed rather common to stay on an Essential Skills visa for a long time', with almost one third of aged care assistants who obtained a first Essential Skills visa in 2008, still on an Essential Skills visa in mid-2012. ${ }^{46}$ Despite the exclusion of care work from the SMC program, some care workers holding visas under the Essential Skills Policy have managed to make the transition to permanent residency in New Zealand. Some achieve this through gaining permanent residency via the Family or Humanitarian streams, others use another occupational category at a higher ANZSCO skill level. For example, of those who were granted an Essential Skills work visa as an aged or disabled carer in 2011-12, 37 per cent secured residence within three years; 73 per cent of those migrants gained residence as a skilled principal migrant with the most common occupation being 'registered nurse' ${ }^{47}$

This is consistent with evidence that it is not only temporary migrant workers who are engaged in care work in New Zealand but migrants who have come through the permanent program as nurses who have been unable to meet the registration or English language requirements once in New Zealand. A study by Walker found that many offshore migration agents did not disclose the requirements of professional registration in New Zealand before arranging for overseas workers to apply for either the temporary program (Essential Skills Policy) or the permanent program (Skilled Migration Category). This has meant that many overseas-trained nurses failed registration and could work only as caregivers or care assistants, which is lower paid. ${ }^{48}$ As part of the registration process, nurses must also pass IELTS or the Occupational English Test - both of which have 'proved a significant barrier to many migrant nurses', with many ending up 'taking up long term care jobs'. ${ }^{49}$

46 OECD, Recruiting Immigrant Workers: New Zealand 2014 (OECD Publishing, 2014) 64.

47 Ministry of Business, Innovation \& Employment, 'Migration Trends and Outlook 2014/2015', above n $40,34$.

48 Léonie Walker, 'A Mixed Picture: The Experiences of Overseas Trained Nurses in New Zealand' [2008] Labour, Employment and Work in New Zealand 433, 434, 437; see also Juthika Badkar, Paul Callister and Robert Didham, 'Ageing New Zealand: The Growing Reliance on Migrant Caregivers' (Working Paper No 09/08, Institute of Policy Studies, July 2009).

49 New Zealand Human Rights Commission, 'Caring Counts' (Inquiry, May 2012) 103, 106 $<$ https://www.hrc.co.nz/files/1214/2360/8576/Caring_Counts_Report.pdf $>$. This is also a challenge in Australia, with many migrant health and social care workers finding their qualifications, skills and experience are not recognised: see Jane Pillinger, 'Quality Healthcare and Workers on the Move' (Australia National Report, Public Services International, November 2012) < http://www.worldpsi.org/sites/default/files/documents/research/psi_australia_report.pdf $>$. 


\section{Side Doors and Back Doors}

As the Essential Skills Policy allows for the migration of workers in lower ANZSCO skill levels, the New Zealand labour migration program does not include any side door pathways. There are still, however, back door routes into the New Zealand labour market, for visa holders on visas with a non-work purpose, although the nature and significance of their labour market impact is unknown.

First, the Working Holiday Schemes allow young people whose primary intention is to holiday in New Zealand to undertake employment and study during their stay in accordance with their scheme. New Zealand currently has 45 Working Holiday Schemes with different partner countries. The number of working holiday makers has increased steadily over the last decade, with 70002 visas approved under the Schemes in 2016-17, representing a 7 per cent increase on the previous year. ${ }^{50}$ The top three source countries of working holiday makers for 2014-15 were Germany, the UK and France. ${ }^{51}$

Second, the international student visa, although for the primary purpose of education, does permit the visa holder to work in New Zealand. During term time an international student's employment must not be for more than 20 hours per week, although this can increase to full-time hours during scheduled breaks. New Zealand's international student visa continues to grow in popularity, with a total of 91575 international students approved to study in New Zealand in 2016-17.52 China, India and South Korea are the three largest source countries under the program..$^{53}$ There is no available data on how many working holiday makers or international students work in the care sector in New Zealand.

In summary, the transformation of New Zealand's regulatory approach to permanent and temporary labour immigration from the 1990s until the present day has been profound. During this period 'change and innovation rather than the stability of policy' were the norm, ${ }^{54}$ with a couple of key themes evident from the many reforms. First, the focus of the permanent program on enabling skilled migration to New Zealand, was supplemented by temporary migration flows through the Essential Skills Policy, which permitted migration to meet labour shortages in a broader range of skill levels. This opened a 'front door' to the New Zealand labour market for frontline care workers. Second, the temporary labour migration program embodied in the Essential Skills Policy provided greater entitlements in terms of length of visa and transitioning to residency for occupations with a higher skill level. This, coupled with the 'work to residence' visa, saw New Zealand explicitly adopt a two-step migration process that created a direct link between temporary migration through to permanent residency for skilled occupations. Care work, categorised as ANZSCO Skill Level 4, was not

50 Ministry of Business, Innovation \& Employment, 'Migration Trends: 2016/2017' (Annual Report, New Zealand Government, March 2018) 27 <http://www.mbie.govt.nz/publicationsresearch/research/migrants---monitoring/migration-trends-2016-17.pdf> .

51 Ibid.

52 Ibid 14.

53 Ibid.

54 Richard Bedford, Elsie Ho and Charlotte Bedford, 'Pathways to Residence in New Zealand, 2003-2010' in Andrew Trlin, Paul Spoonley and Richard Bedford (eds), New Zealand and International Migration: A Digest and Bibliography, Number 5 (Massey University, 2010) 1, 3. 
eligible for this transition, although notably, many care workers have successfully converted to permanent residency despite this regulatory constraint. Third, the countries of origin of temporary migrants have changed over time (and therefore so has the composition of the permanent program), and for care workers, the primary source countries are from South Asia and the Pacific. Many of these migrants appear to be long-term temporary migrants with no ability to meet the eligibility requirements under the SMC or other permanent migration pathways, and subject, on an annual basis, to the uncertainty of their employer meeting the labour market testing requirement, which has become far more sophisticated and challenging over time.

Although working holiday makers can work in the care sector, these visa holders seem less likely to be a core component of the care workforce in New Zealand than in Australia, where as we explain below, the primary source countries of working holiday makers are increasingly Asian countries with high wage differentials to Australia. Although international students can work in care in New Zealand, the scale of their contribution is unknown and limitations on their ability to work during semester are likely to constrain their involvement in care work. Thus, whilst New Zealand's regulatory approach to migration has undergone significant transition in thinking about 'international migration as a process [and] immigration policy as a strategy for achieving desired national outcomes', ${ }^{55}$ for frontline care workers the migration pathway presents a distinct set of challenges. The Essential Skills Policy creates a precarious migrant care workforce with no straightforward route to permanent residency. These two issues are present in the Australian case study below and we will revisit them in more depth in the final section of the article.

\section{B Australia}

As in New Zealand, Australia's regulatory approach to managing labour migration has undergone radical transformation from the 1990s to the present day. Although Australia's post-WWII migration program was founded upon the ideals of permanent migration, nation-building and citizenship, ${ }^{56}$ temporary labour migration has now become the norm. The number of temporary labour migrants has quintupled since $1996 .{ }^{57}$ Although only the Temporary Skill Shortage visa and new labour market programs for Pacific workers are for a dedicated work purpose, both international students and working holiday makers have work rights and a significant amount of what is deemed 'unskilled' and 'low-skilled' work is done

55 Ibid 40.

56 Mary E Crock, 'Contract or Compact: Skilled Migration and the Dictates of Politics and Ideology' (2001) 16 Georgetown Immigration Law Journal 133.

57 There were 25786 subclass 457 visa grants in 1996-97 compared with 125070 in 2011-12: see Janet Phillips and Harriet Spinks, 'Skilled Migration: Temporary and Permanent Flows to Australia' (Background Note, Department of Parliamentary Services, 6 December 2012) 40 (Table 3); Department of Immigration and Citizenship, 'Trends in Migration: Australia 2010-11' (Annual Submission, February 2012) 37 . 
by temporary migrants on these visas. ${ }^{58}$ As in New Zealand, the composition of the temporary program influences the permanent program. Temporary migration is now a vital source of permanent migrants with the majority of skilled migrants in the permanent visa stream having initially entered and worked in Australia as temporary migrants. ${ }^{59}$

\section{Front Doors}

The main labour migration pathway is the Temporary Skill Shortage (TSS) visa which does not allow for the temporary migration of frontline care workers. The TSS visa draws upon the previous 457 visa framework but with some important modifications. The TSS has two streams. The first stream is for occupations that have been identified as being of high value to the Australian economy and aligned to the government's longer term training and workforce strategies. This stream allows a visa term of 4 years and provides a pathway to permanent residency. The second stream has been called the 'short-term stream' and is for occupations for which there is an immediate need. This has been designed as a purely temporary stream, with the visa expiring after two years and with no access to permanent residency.

As with the 457 visa, the TSS visa does not allow for the temporary migration of frontline care workers. However, there were certain periods in the 457 visa's history where temporary migrant care workers were permitted front door entry into the Australian labour market, which are important to examine briefly. During the early 2000 s, the 457 visa was 'deregulated' 60 and opportunities arose for employers to access lower-skilled workers, despite the official orientation of the program being for skilled temporary migrant workers. ${ }^{61} \mathrm{~A}$ regional agreement stream was created, ${ }^{62}$ which allowed regional employers to form regional agreements if they applied for a certificate from the Regional Certificating Body that 'the position cannot reasonably be filled locally' ${ }^{63}$ From late 2002, a provision existed to waive the salary and skill thresholds for the 457 visa for regional agreements so that employers in regional areas were permitted to pay their workers only 90 per cent

58 Howe and Reilly, above n 32; Boucher, 'Australia’s De Facto Low Skilled Migration Programs', above n 19.

59 Approximately 50000457 visa holders became permanent residents in 2015-16, 'making up close to 40 per cent of Australia's total annual (permanent) skilled migration intake': see Peter Mares, 'The 457 Visa is Dead! Long Live the TSS?', Inside Story (online), 20 April $2017<$ http://insidestory.org.au/the-457visa-is-dead-long-live-the-tss/>.

60 Iain Campbell and Joo-Cheong Tham, 'Labour Market Deregulation and Temporary Migrant Labour Schemes: An Analysis of the 457 Visa Program' (2013) 26 Australian Journal of Labour Law 239.

61 Howe, 'Is the Net Cast Too Wide?', above n 32.

62 Migration Regulations 1994 (Cth) reg 1.20GA(1)(a)(iii), as repealed by Migration Amendment Regulatoins 2009 (No 5) (Cth).

63 Department of Immigration and Citizenship, Australian Government, Frequently Asked Questions: Permanent Employer Sponsored Program Reforms July 2012 (May 2012) 14 $<$ https://rdanorthernrivers.org.au/download/industry_and_economic_development/rsms/rsms-pesfaq.pdf $>$. 'Regional' was broadly defined. The only employers excluded from making a regional agreement were employers in Sydney, Newcastle, Wollongong, Melbourne, Brisbane, the Gold Coast and Perth: Bob Kinnaird, 'Current Issues in the Skilled Temporary Subclass 457 Visa' (2006) 14 People and Place 49, 51. 
of the minimum salary requirement. ${ }^{64}$ Employers were also able to engage workers for occupations deemed as being of lower skill such as a 'Personal Care Assistant' identified as an Australian Standard Classification of Occupations ('ASCO') Skill Level 6 occupation. ${ }^{65}$

Propelled by integrity concerns and the growing use of the 457 visa for lowerskilled occupations, significant reforms to the 457 visa were made in 2008-09 which abolished the front door labour migration pathway for frontline care workers. This followed a number of comprehensive reviews into the program, ${ }^{66}$ which each saw a strong desire to avoid the 457 visa shifting from its original anchorage as a skilled migration program. In 2008 the Visa Subclass 457 External Reference Group reported the 457 visa had become, by default, a 'general labour supply visa' and advocated it be rebalanced in favour of skilled temporary migration. ${ }^{67}$ This echoed an earlier sentiment made by the Joint Standing Committee on Migration in 2007 strongly opposed to the 457 visa being used to meet unskilled labour shortages as it would 'put at risk its acceptability to the general community' ${ }^{68}$ The Deegan Report also argued for a rigorous compilation of the occupational shortage lists so as to ensure that genuine skill shortages existed in the occupations that could be sponsored by employers. The rationale for this was to avoid the 'risk of the visa program being manipulated to import unskilled labour, or skilled labour where there is a plentiful supply available locally'. ${ }^{69}$

As a result of these reviews, the federal government abolished the regional agreements stream under the 457 visa and the concessional minimum salary rate for regional employers,$^{70}$ thereby removing a front door migration pathway for frontline care workers. ANZSCO Skill Level 5-7 occupations were no longer eligible for temporary labour migration to the regions. Employers wishing to access lower-skilled temporary migrant workers had to now do so via the labour agreement pathway. Additionally, the minimum salary rates requirement was replaced by a new market salary rates requirement and a salary floor for temporary

64 Janet Phillips, 'Temporary (Long Stay) Business Visas: Subclass 457' (Research Note No 15, Parliamentary Library, Parliament of Australia, 21 February 2007) 2.

65 Australian Bureau of Statistics, 'Australian Standard Classification of Occupations (ASCO) Second Edition’ (No 1220.0, 31 July 1997)

<http://www.abs.gov.au/ausstats/abs@.nsf/0/7F887D870E0673BECA25697E00185133?opendocument>.

Visa Subclass 457 External Reference Group, 'Final Report to the Minister for Immigration and Citizenship' (Department of Immigration and Citizenship, 23 April 2008)

$<$ https://www.voced.edu.au/content/ngv:41113>; Joint Standing Committee on Migration, 'Temporary Visas ... Permanent Benefits: Ensuring the Effectiveness, Fairness and Integrity of the Temporary Business Visa Program' (Parliament of Australia, August 2007); Barbara Deegan, 'Visa Subclass 457 Integrity Review' (Final Report, October 2008)

$<$ https://archive.homeaffairs.gov.au/WorkinginAustralia/Documents/457-integrity-review.pdf $>$ ('Deegan Report').

67 Visa Subclass 457 External Reference Group, above n 66, 37.

68 Joint Standing Committee on Migration, 'Temporary Visas ... Permanent Benefits', above n 66, 12.

69 Deegan Report, above n 66, 34.

70 Australian Government, 'Temporary Visas ... Permanent Benefits: Ensuring the Effectiveness, Fairness and Integrity of the Temporary Business Visa Program: The Government Response to the Report' (Report, Parliament of Australia, 12 September 2007) 10. 
migrant workers on the 457 visa. ${ }^{71}$ Another set of reforms occurred in 2013 when employer-conducted labour market testing was introduced for certain occupations and the market salary rates requirement was strengthened. ${ }^{72}$

Thus, in its final iteration before it morphed into the TSS, the 457 visa only permitted entry of ANZSCO Skill Level 1-3 occupations and therefore, did not provide a temporary migration pathway for the occupations of 'aged or disabled carer', 'child care worker', and 'personal care assistant', all of which are designated as ANZSCO Skill Level $4 .^{73}$ This approach was continued with the introduction of the TSS visa. Nonetheless, the 457 visa and its successor, the TSS visa, does permit the entry of secondary visa holders (partners and dependents of the primary visa holder) who are not subject to the same restrictions as the primary visa holder, and may undertake work at any skill level. Although there is no collected data on the work contribution of secondary visa holders it is likely that some of this group is employed in frontline care work.

Aside from the TSS, the development of new labour migration programs for Pacific workers provides new, albeit small, front doors facilitating the temporary migration of care workers from the Pacific into the Australian labour market. The rationale for these new initiatives is to expand employment opportunities particularly for women - while developing skills and increasing remittance flows, ${ }^{74}$ and responding to labour market needs in the Australian economy. In 2016 a new five year pilot programme was introduced which provides up to 250 places for workers from the Pacific microstates with access to a three year Microstate Pilot Visa ('MPV') to work in lower-skilled occupations in Northern Australia. ${ }^{75}$ Although this pilot targets non-seasonal occupations with identified labour shortages such as accommodation, tourism, hospitality and aged care, visa holders are eligible to work in any sector. ${ }^{76}$ The first group of workers arrived in October 2016 and was employed in housekeeping and stewarding roles. ${ }^{77}$ More groups of Pacific microstates visa workers are planned to arrive and two aged care employers are registered with the Department of Foreign Affairs and Trade ('DFAT') as eligible to access workers under the program, with a third aged care provider currently in negotiations with DFAT. ${ }^{78}$

In September 2017 this approach to regional development and labour market challenges in Australia was extended with the announcement of a new Pacific

71 For an analysis of these reforms, see Joanna Howe, 'The Migration Legislation Amendment (Worker Protection) Act 2008: Long Overdue Reform, but Have Migrant Workers Been Sold Short?’ (2010) 23 Australian Journal of Labour Law 251.

analysis of these reforms, see Howe, 'Is the Net Cast Too Wide?', above n 32. As of 1 July 2010, the DIBP began using ANZSCO instead of ASCO to classify occupations. Australian Government, 'Our North, Our Future: White Paper on Developing Northern Australia' (White Paper, June 2015) <http://northernaustralia.gov.au/files/files/NAWP-FullReport.pdf>. See also Joint Standing Committee on Migration, 'Seasonal Change: Inquiry into the Seasonal Worker Programme' (Report, Commonwealth of Australia, May 2016) 5 [2.8].

75 Ibid 6 [2.10], 13 [2.34].

76 Radio Australia, Pacific Beats, 17 October 2016 (Concetta Fierravanti-Wells) $<$ http://ministers.dfat.gov.au/fierravantiwells/transcripts/Pages/2016/cf_tr_161017.aspx?w=p2wUlmE1t7kK11\%2BiOm3gqg\%3D\%3D>. Ibid.

78 Ibid. 
Labour Scheme ('PLS'). The PLS extends and formalises the Microstates Pilot Visa scheme in a range of ways and singles out the care sector as the largest of three growth sectors covered by the PLS. ${ }^{79}$ The PLS is an employer-sponsored scheme that will commence in July 2018 with an initial intake of 2000 workers from Kiribati, Nauru and Tuvalu, in keeping with the MPV's emphasis on extending developmental benefits of labour migration to the smallest Pacific Island Countries ('PICs'). Recruitment will take place via a new Pacific Labour Facility ('PLF'), intended to allow DFAT to mediate between employers and PIC workers for Seasonal Worker Programme and PLS recruitment. As the PLS is still being designed and developed, at this stage it is difficult to assess the significance of this front door migration pathway for frontline care workers.

Aside from the myriad of temporary labour migration pathways, Australia's permanent program is also highly significant, both in terms of the number of workers and the complexity of its design. Australia's migration program consists of 190000 places, with 128550 of these allocated for skilled migrants. ${ }^{80}$ There is no provision for the permanent migration of frontline care workers unless they can apply under a different occupational category such as 'Child Care Centre Manager' or 'Registered Nurse (Aged Care)' both of which include a mandatory skills testing assessment by an independent authority. ${ }^{81}$ Migrant refugees provide one possible source of labour for the care sector from the permanent program, although their capacity to find and secure work is often limited by a lack of local networks, local work experience and in some cases, English language ability. ${ }^{82}$ Once an asylum seeker has been given refugee status, they have unlimited work rights in Australia. A report by Anglicare Australia provides a case study of a number of refugee migrants who have found jobs in the aged care sector in Victoria through a transition to work program coordinated by the Brotherhood of St Lawrence..$^{83}$ The Given the Chance program is designed to target the needs of refugees and provide support to both the employer and the worker to ensure the long-term sustainability of their employment relationship. ${ }^{84}$ Similarly, a report analysing the Limestone Coast region in South Australia found a strong reliance on migrant workers in aged care who had obtained permanent residency in Australia through the humanitarian visa pathway and had a 'good reputation as reliable and hard working'. ${ }^{85}$ Additionally, partners and children of primary visa holders entering Australian

79 Department of Foreign Affairs and Trade 2017c. 'Pacific Labour Scheme'. Canberra: Australian Government, Department of Foreign Affairs and Trade.

80 Productivity Commission, 'Migrant Intake into Australia: Productivity Commission Inquiry Report' (Inquiry Report No 77, 13 April 2016) 75.

81 Ibid.

82 See generally, Graeme Hugo, 'A Significant Contribution: The Economic, Social and Civic Contributions of First and Second Generation Humanitarian Entrants' (Summary of Findings, Department of Immigration and Citizenship, 2011).

83 Anglicare Australia, 'Positions Vacant?: When the Jobs Aren't There' (Family Report, October 2016) 39 $<$ http://www.anglicare.asn.au/docs/default-source/default-document-library/sotf2016a8c6d6309d6962baacc1ff0000899bca.pdf?sfvrsn=0>. Ibid 43-4.

85 Helen Feist et al, 'Enabling Rural Migrant Settlement: A Case Study of the Limestone Coast' (Report, 2014) 75 . 
through the permanent migration program are eligible to work in any sector and undoubtedly, many (although the extent is unknown) work in frontline care work. ${ }^{86}$

\section{Side Doors}

With the front door closed to frontline care workers outside of the Pacific, the migration of care workers to Australia has been possible on a temporary basis through the labour agreement stream. Attached to the standard skilled migration pathway through the TSS visa and its predecessor, the 457 visa, there exists a 'labour agreements' pathway that allows employers to access workers who do not have the work skills or English language ability required under the standard pathway. The labour agreements stream has existed since the inception of the 457 visa scheme in 1996 and its chief attraction for employers is the ability to access workers in occupations categorised as ANZSCO Skill Levels 4-7 and the opportunity to negotiate concessions on the regulatory requirements associated with the standard 457 visa. Labour agreements must meet a 'no less favourable' requirement to ensure that the wages and conditions of the 457 visa worker are commensurate to the equivalent domestic worker, ${ }^{87}$ and a labour market testing requirement. Because labour agreements have to be individually negotiated over a period of months with the Department of Home Affairs, the intention is that safeguards can be embedded within the labour agreement making process to protect job opportunities for local workers and the vulnerability of the temporary migrant workers. However, this regulatory approach is by no means foolproof as persistent calls from employer groups to deregulate and simplify the labour agreement process, means that the integrity of the labour agreement pathway is contingent upon ministerial discretion regarding the framework for how labour agreements should be negotiated. ${ }^{88}$

An important step in improving the public transparency and accountability of the labour agreements stream was the decision in 2017 to release publicly the names of businesses using a labour agreement and to update this on a quarterly basis. ${ }^{89}$ Although the utility of this information is of limited value, as the webpage does not provide information on the concessions granted, how many migrant workers are permitted entry under each labour agreement and for which locations, it does provide an indication of the types of industries and employers that are using

86 Our analysis of the Australian Census and Migrants Integrated Dataset ('ACMID') 2011, which provides data on migrants on a permanent visa only, indicates that in 2011 there were some 27379 child carers, aged and disabled carers and personal care workers who had migrated to Australia since 2001 and who held a permanent visa as of August 2011. This cohort of more recently arrived frontline care workers made up around 44 per cent of all the overseas born in these occupations, with the remainder mainly having arrived in Australia before 2001. See Australian Bureau of Statistics, 'Microdata: Australian Census and Migrants Integrated Dataset, 2011' (14 February 2014)

$<$ http://www.abs.gov.au/AUSSTATS/abs@.nsf/Lookup/3417.0.55.001Main+Features12011>.

87 Migration Regulations 1994 (Cth) reg 2.79.

88 Howe and Reilly, above n 32.

89 For two critiques, see Joo-Cheong Tham, 'Law-Making and Temporary Migrant Labour Schemes: Accountability and the 457 Visa Scheme' (2009) 17 Australian Journal of Administrative Law 18. For an examination of the problems of accountability and transparency with the subclass 457 visa program in general, see Joanna Howe, 'Accountability and Transparency under the Subclass 457 Visa Program: Is There Cause for Concern?’ (2014) 21 Australian Journal of Administrative Law 139. 
the labour agreements stream. ${ }^{90}$ On the list updated on 30 June 2017, there were two company-specific labour agreements with care employers, 'Fronditha' and 'Baptist Care'. The list also identified that the Northern Territory's DAMA, which is explored in more detail below, has a number of care employers registered to bring in migrant care workers, including 'Alyangula Daycare', 'Anglicare NT', 'Arnhem Early Learning Centre' and 'Territory Child Care Group'. Although there has been no public release on the historical use of labour agreements, a previous Freedom of Information request identified that between 2012-15 there were two labour agreements for the aged care sector with the employers located in Victoria and Western Australia. ${ }^{11}$ Under these agreements, 25 primary visas were granted for occupations 'residential care officer', 'nursing support worker' and 'personal care assistant'. ${ }^{92}$

One of these labour agreements was negotiated between Fronditha Care and the DIBP, which was hailed by the then Assistant Minister for Immigration, Senator Michaelia Cash, as an opportunity for Fronditha Care to recruit bilingual aged carers to meet the culturally-specific needs of its elderly Greek patients. ${ }^{93}$ As part of its labour agreement, Fronditha Care became the first service provider in the Australian health industry to be able to employ 20 bilingual personal care workers a year over three years. As a result of the labour agreement Fronditha Care candidates have a lower-skills threshold to meet than skilled worker migrants under the standard pathway. They need a Certificate III in aged care, as do most personal care workers in residential aged care, and good English language proficiency. A recent analysis of the Fronditha Care labour agreement found that most of Fronditha's recruits via the labour agreement were on-shore applicants (meaning they were already living in Australia), mainly as international students. ${ }^{94}$ Mares writes of the significant time and monetary investment made by on-shore applicants to work for Fronditha in completing a Certificate III in aged care, 180 hours of unpaid work as part of a course requirement to complete a placement and the need to attain a Level 5 in the English language test. He also depicts the strong desire of Fronditha's labour agreement workers for permanent residency and their desire for employer sponsorship, although this is by no means guaranteed through

90 Department of Home Affairs, List of Current Labour Agreements (12 November 2018) $<$ https://immi.homeaffairs.gov.au/visas/employing-and-sponsoring-someone/sponsoringworkers/nominating-a-position/labour-agreements/list-of-current-labour-agreements>.

91 Department of Immigration and Border Protection, 'Subclass 457 Primary Visas Granted between 2012 13 and 2014-15 under a Labour Agreement in Selected Nominated Occupations by Nominated Position Location' < https://archive.homeaffairs.gov.au/AccessandAccountability/Documents/FOI/20160708FA160500727-Documents-Released.pdf > . (Document released by the DIBP in 2016 under the Freedom of Information Act 1982 (Cth)).

92 Ibid.

93 See, eg, 'Immigration Department in Deal with Fronditha Care to Recruit Greek Bilingual Workers', Herald Sun (online), 1 August $2014<$ http://www.heraldsun.com.au/news/victoria/immigrationdepartment-in-deal-with-fronditha-care-to-recruit-greek-bilingual-workers/newsstory/0112880f5f7cca42c5c94694629710e5>. See also the employer's labour agreement information brochure: Fronditha Care, 'Labour Agreement Information Booklet' (2013) $<$ http://frondithacare.org.au/wp-content/uploads/2013/07/LA-BROCHURE_PRINT-READY.pdf $>$.

94 Peter Mares, Not Quite Australian: How Temporary Migration is Changing the Nation (Text Publishing, 2016) 211. 
the Employer Nomination Program because of their lower skill level. Mares largely considers the Fronditha labour agreement to be a success, observing that it 'illustrates that despite the many potential pitfalls of temporary migration, it can work well, delivering positive outcomes for employers, migrants, the community and the nation. ${ }^{95}$

Labour agreements into particular regions in Australia are also made possible through a DAMA. ${ }^{96}$ DAMAs enable employers to access temporary migrant labour through an umbrella agreement which has been negotiated between a designated area representative such as a council or government body. Individual employers can apply to the designated area representative for a labour agreement which sits underneath the umbrella agreement. The DAMA guidelines permit concessions to be made on salary, occupation and English language requirements contained within the TSS visa program.${ }^{97}$ Whereas the TSS visa only permits entry of workers sponsored to work in occupations categorised as ANZSCO Skill Level 1-3, the DAMA program permits workers to be sponsored to work in ANZSCO Skill Level 4 occupations..$^{98}$ The first DAMA has been finalised for the Northern Territory and includes a number of care occupations, including 'family day care worker', 'personal care assistant', 'residential care worker', 'childcare worker' and 'aged or disability carer' ${ }^{99}$ Because these occupations are classified as 'vulnerable', an English language concession is not allowed, however a visa holder under a DAMA working in these occupations can receive a lower salary than the Temporary Skilled Migration Income Threshold ('TSMIT'). ${ }^{100}$ Care workers entering under a DAMA are subject to a stricter skills testing regime than higher-skilled workers. They are required to have their skills assessed once in Australia, with their work experience verified as being genuine and their employer must complete a statutory declaration confirming that the visa holder has the necessary work experience and qualifications required to meet the requirements of the occupation. ${ }^{101}$ Employers are required to apply to the DAMA administrator in order to sponsor workers and are subject to certain labour market testing requirements, although as these are largely based on employer attestation of labour shortages, the rigour of this measure is somewhat questionable. ${ }^{102}$ Although only one DAMA has been approved by the federal government thus far, this program does open a migration pathway for temporary migrant care workers to work in Australia in certain

95 Ibid 214.

96 Department of Immigration and Border Protection, 'Designated Area Migration Agreements', above n 12.

97 Ibid 8-9.

98 Ibid.

99 Migration Corporation of Australia, 'Occupations Accessible under the DAMA' (2016)

$<$ http://www.migrationcorporation.com.au/wp-content/uploads/2016/04/04.2016-Occupations-accessibleunder-the-DAMA.pdf $>$.

100 Ibid.

101 Migration Corporation of Australia, 'DAMA FAQs - Factsheet 4: Market Rates' $<$ http://www.migrationcorporation.com.au/wp-content/uploads/2015/01/DAMA-FAQs-1.pdf $>$.

102 Joanna Howe, 'Does Australia Need an Expert Commission to Assist with Managing its Labour Migration Program?' (2014) 27 Australian Journal of Labour Law 233. 
locations and subject to a number of additional conditions to the standard TSS visa program.

\section{Back Doors}

A number of visas for a non-work related purpose exist but are important to the overall picture of care migration because a significant amount of work is performed by these visa holders. Working holiday visas (visa subclasses 417 and 462) allow temporary migrants from 41 countries of between 18 and 30 years of age to work while they holiday in Australia for up to a year. ${ }^{103}$ Working holiday visas provide work entitlements for the full 12 months of their visa, but only six months work with any one employer. ${ }^{104}$ In November 2005, the law was changed to make it possible for working holiday visa holders to apply for a second working holiday visa if they have worked for three months in 'specified work' in mining, construction and agriculture in regional Australia. ${ }^{105}$ Despite this visa being for a non-work related purpose, the DIBP has acknowledged the work motive of working holiday makers. It reports that the recent increase in working holiday makers 'largely appears to be associated with the wider global economic situation' in 2011-12 as labour market opportunities in some 'partner countries remain uncertain. ${ }^{106}$ Numbers in the program have risen steadily since its inception. ${ }^{107}$ The enhanced interest from young Taiwanese and South Korean workers in obtaining a second year on the Working Holiday Maker visa could be linked to the 'substantially lower minimum wage frameworks in both countries', ${ }^{108}$ a point noted by the Fair Work Ombudsman. ${ }^{109}$ Notably, the top three source countries of working holiday makers applying for a second year on the Working Holiday visa are the United Kingdom, Taiwan and South Korea. ${ }^{110}$

Although scholars have noted the significant labour market impact of working holiday makers, ${ }^{111}$ official government documents consistently affirm the "cultural exchange' purpose of the programme with 'work incidental to the purpose of the

103 See Department of Home Affairs, ‘Working Holiday Maker Visa Program Report' (Report, 31 December 2017) 3 <https:/www.homeaffairs.gov.au/research-and-stats/files/working-holiday-report-dec17.pdf>. Australia has also signed Work and Holiday visa agreements with Austria, the Czech Republic, Ecuador, Greece and Papa New Guinea but these agreements were not yet in effect as at 31 December 2017.

104 Migration Regulations 1994 (Cth) regs 417.611, 462.611. See also, Department of Immigration and Citizenship, 'Working Holiday Maker Visa Program Report' (Report, 30 June 2013) 4.

105 Department of Immigration and Citizenship, 'Working Holiday Maker Visa Program Report', above n 104.

106 Ibid 7.

107 Department of Immigration and Border Protection, 'Working Holiday Maker Visa Programme Report' (30 June 2015) $7<$ https://www.homeaffairs.gov.au/research-and-stats/files/working-holiday-reportjune15.pdf $>$.

108 As of 1 July 2015 the minimum wage was \$5.06 AUD in Taiwan and \$6.69 AUD in South Korea, compared to \$17.29 in Australia.

109 Fair Work Ombudsman, 'Inquiry into the Wages and Conditions of People Working under the 417 Working Holiday Visa Program’ (Commonwealth of Australia, October 2016) 10.

110 Department of Home Affairs, 'Working Holiday Maker Visa Program Report', above n 103, 7.

111 See, eg, Howe and Reilly, above n 32; Alexander Reilly, 'Low-Cost Labour or Cultural Exchange? Reforming the Working Holiday Visa Programme' (2015) 26 Economic and Labour Relations Review 474. 
visa'. ${ }^{112}$ The Department of Home Affairs states in its policy guidance that 'work in Australia must not be the main purpose of the visa holder's visit'. ${ }^{113}$ It is significant, then, that in a number of places, the Explanatory Memorandum for a 2016 reform package for the Working Holiday Maker visa recognises the central role of the Working Holiday Maker scheme in meeting labour shortages in the Australian economy. ${ }^{114}$ This promoted the work contribution of these visa holders and suggests that a shift is taking place amongst policymakers' perspective of the role of this visa. For example, the Explanatory Memorandum states that its proposed reforms 'recognise the important contribution of working holiday makers to the Australian economy', 115 the program's role as 'a strong contributor of supplementary labour', ${ }^{116}$ and visa holders' role as 'drivers of future economic growth' ${ }^{117}$ This official acknowledgment of the work contribution of working holiday makers was coupled with changes to allow working holiday makers to work for the same employer for 12 months in two separate regions.

Other regulatory modifications of the Working Holiday Maker scheme have specifically sought to enable these visa holders to perform what are designated as low-skilled care jobs in Australia. The first initiative, which commenced in late 2015, ${ }^{118}$ enabled Working Holiday (subclass 417) and Work and Holiday (subclass 462) visa holders to seek an extension to work for up to 12 months with the same employer in Northern Australia in aged and disability care as it is deemed a 'high demand industry'. A number of work activities are eligible for this extension: aged care residential services, disabilities assistance services, aged care assistance services and aged or disability carer. ${ }^{119}$ The second initiative provides permission to be granted for au pairs to work on a 12 months' basis for a single employer. ${ }^{120}$ To be considered an au pair, the visa holder's primary responsibility must be the care of a family's children, rather than any domestic work. ${ }^{121}$

112 Department of Immigration and Citizenship, 'Working Holiday Maker Visa Program Report', above n 104,3 .

113 Department of Home Affairs, What is the Working Holiday Maker Program?

$<$ https://archive.homeaffairs.gov.au/lega/lega/form/immi-faqs/what-is-the-working-holiday-makerprogram $>$ (emphasis added).

114 Income Tax Rates Amendment (Working Holiday Maker Reform) Act 2016 (Cth).

115 Explanatory Memorandum, Income Tax Rates Amendment (Working Holiday Maker Reform) Bill 2016 (Cth) 10 [1.4].

116 Ibid 43 [3.12].

117 Ibid 49 [3.39].

118 This initiative took effect as of 21 November 2015. See Janet Phillips, 'Australia's Working Holiday Maker Program: A Quick Guide’ (Research Paper Series 2016-17, Parliamentary Library, Parliament of Australia, 22 November 2016).

119 More information can be found on the Department of Home Affairs' website: Department of Home Affairs, Working in Australia - Six Months with One Employer $<$ https://archive.homeaffairs.gov.au/trav/work/empl/whm-six-months-one-employer>.

120 This change took effect as of 21 July 2015. For a copy of the form (Form 1445) see: Department of Immigration and Border Protection, 'Request Permission to Work with an Employer Beyond 6 Months', above $\mathrm{n} 14$.

121 Laurie Berg, 'Hiding in Plain Sight - Au Pairs in Australia' in Rosie Cox (ed), Au Pairs' Lives in Global Context: Sisters or Servants? (Palgrave Macmillan, 2015) 187. 
International students are permitted to work part-time during the course of their studies. ${ }^{122}$ Since 2008 , the opportunity to work has been automatically included in student visas whereas previously students had to apply to be able to work. In 2013, international students became eligible for Graduate (Temporary) Visa subclass 485 to provide new opportunities to live and work in Australia after the completion of their course of study. The rationale for the liberalisation of work rights for international students is to give Australia a competitive advantage over its major competitors for international students, the United States ('US'), Canada and the UK where work rights either do not exist or are not as generous. ${ }^{123}$ It is unclear precisely how many international students work in frontline care jobs, although our analysis of the 2016 Australian Bureau of Statistics labour force survey on key characteristics of recent migrants suggests that around 18000 migrants working in frontline care occupations held a temporary student visa on arrival. ${ }^{124}$

This picture reveals a current Australian labour migration program with myriad doors each of which provide visa holders with a varying degree of tenure, status and security in Australia. Previously many migrants who have worked as frontline care workers arrived as permanent migrants. Today, a growing proportion of newly arrived frontline care workers rely on temporary side door and back door labour migration pathways to enter the Australian labour market. A striking aspect of the Australian regulatory approach to migration law and policy is the dominant role of employers in determining the composition of the temporary and permanent labour migration programs with the ascendancy of the demand-driven model after 1996. Two entry channels (special visas for Pacific workers and labour agreements) seek to address the labour needs of particular regions or particular employers by reference to an employer-sponsorship model. These pathways each include additional regulatory safeguards to ensure that the vulnerability of visa holders coming through these pathways is addressed, although it is uncertain the extent to which these safeguards adequately protect these workers from exploitation at work and non-compliance with Australian labour law. Two other back door temporary labour migration channels involve temporary visas for a nonwork related purpose and allow the performance of frontline care work but without any additional labour market protections to account for their vulnerability. Both international students and working holiday makers perform a significant amount of low and semi-skilled work in Australia, some of which is in care. Their

122 See generally, Alexander Reilly, 'Protecting Vulnerable Workers: The Case of International Students' (2012) 25 Australian Journal of Labour Law 181.

123 For Canada, see Immigration and Citizenship, Government of Canada, Work Off Campus as an International Student $(27$ December 2017) <http://www.cic.gc.ca/english/study/work-offcampus.asp>. For the UK, see UK Visas and Immigration, 'Immigration Rules' (Policy Paper, 31 January 2012) para $245 \mathrm{ZW}$

$<$ https://assets.publishing.service.gov.uk/government/uploads/system/uploads/attachment_data/file/27106 0/29nov13___.pdf $>$. In relation to the US, see Aisha Labi, 'Britain's New Student Visa Policy Tightens Restricts Work but Not as Much as Feared', The Chronicle of Higher Education (online) March 222011 $<$ https://www.chronicle.com/article/Britains-New-Student-Visa/126862>. For Australia, see Department of Home Affairs, Check Visa Details and Conditions $<$ https://www.homeaffairs.gov.au/Trav/Stud/More/Work-conditions-for-Student-visa-holders>. Australian Bureau of Statistics, 'Characteristics of Recent Australian Migrants Survey', above n 9. 
contribution in the labour market needs to be accounted for, especially in light of recent reforms to both visas which further promote the performance of work. Additionally, recently settled migrants and secondary visa holders also feature in Australia's care workforce.

\section{CRITIQUE AND ANALYSIS OF TRANS-TASMAN REGULATORY APPROACHES TO MANAGING THE MIGRATION OF FRONTLINE CARE WORKERS}

The preceding part exposed how the various labour migration pathways for frontline care workers into Australia and New Zealand rely upon a gendered construction of skill. Because frontline care work is deemed 'low-skill', in neither country is there a willingness to provide a direct front door for frontline care workers as part of the permanent migration program. Instead, these workers are channelled through temporary visas that provide no linear conversion process to permanent residency. Although in New Zealand the Essential Skills Policy is a front door for frontline care workers, this visa only lasts for 12 months before a renewal request involving labour market testing is required. It is akin to labour agreements, a side door pathway within the Australian program, which enables regions, industries and employers to negotiate an agreement with the Department of Home Affairs to bring in frontline care workers. Today, in both countries, partner visas, special arrangements for Pacific workers and back doors for backpackers and international students enable the performance of frontline care work by other types of visa holders. In this part we explore how these different doors are significant both in regulating employer requests to access migrant care workers and producing precarious labour market status for workers. The type and nature of the door has important ramifications for the ease in which employers can access frontline care workers and the protection of migrant workers coming in via the front door and side door or back door pathways.

\section{A Employer Requests to Access Frontline Care Workers from Overseas}

In managing the migration of frontline care workers, both New Zealand and Australia have relied upon notions of 'skill shortages' and 'labour shortages' in order to scrutinise employer requests to access migrant workers. A stated objective of both countries' migration programs is to meet skill needs. ${ }^{125}$ In New Zealand, more than Australia, there has been greater acceptance of the notion that it is appropriate for 'labour shortages' rather than just 'skill shortages' to be met through the creation of front door pathways for temporary migrant workers in lower ANZSCO-rated occupations where a labour shortage is deemed to exist via

125 Migration Act 1958 (Cth) s 140AA refers to a legislative purpose of meeting 'genuine skill shortages'. The Instructions for the Essential Skills Policy in W1(b)(i) refers to an objective of facilitating access to New Zealand employers and industry to 'global skills and knowledge': see Ministry of Business, Innovation \& Employment, 'New Zealand Operational Manual: Temporary Entry' (New Zealand Immigration, 8 May 2017) 5 <https://screenguild.co.nz/resources/Documents/temporary-entry-2.pdf>. 
labour market testing. New Zealand's Essential Skills Policy is a 'dedicated' labour migration program, whereas in Australia, except for a brief experiment in the early 2000s with a 'regional 457 visa', the migration pathway for frontline care workers has been less clearly delineated in the regulations and occurred through de facto, side door and back door arrangements such as labour agreements and visas for backpackers and international students. These different doors have produced different burdens upon employers attesting to a shortage of frontline care workers.

Front door arrangements such as the TSS and ESP require less from employers in proving that a labour shortage exists. In New Zealand, the ESP initially relied on employer attestation of a labour shortage, but since 2016 it requires employers to first engage with Work and Income to ensure no local New Zealander worker is available to fill the vacancy. ${ }^{126}$ If no local worker is found, Work and Income generate a 'Skills Match Report' to establish a consistent information statement about the skills required for the job. ${ }^{127}$ This report is needed to enable employers to access frontline care workers via the Essential Skills Policy. In contrast, the side door arrangement in Australia requires employers to provide evidence beyond the labour market testing requirement for the TSS by demonstrating that there is a 'genuine labour market need' and that 'recent, genuine efforts' to recruit local workers have been made. ${ }^{128}$ Home Affairs encourages employers seeking to negotiate a labour agreement to provide evidence about their attendance and involvement in careers expos, industry or other labour market research and letters of support from state government authorities with responsibility for employment. Labour agreements also require employers to consult with unions and industry bodies in making an application to access overseas workers. Thus, front door arrangements such as the ESP tend to impose less on employers than side door arrangements. This is in contrast to back door arrangements which do not require employers to demonstrate a labour market need before accessing backpackers or international students. However, as these visa holders are necessarily time bound and subject to work conditions in their visa, the ability of these back door arrangements to deliver a sustainable frontline care workforce is limited.

A related issue for both New Zealand and Australia is the effectiveness of employer-attestation as a means of determining the existence of occupations experiencing labour shortages. Although the reliability and usefulness of employer-conducted labour market testing has been repeatedly debunked as a reliable means of identifying labour shortages ${ }^{129}$ both countries rely, to varying

126 Immigration New Zealand, 'Amendments to the Immigration New Zealand Operational Manual' (Circular No 2016/03, 7 April 2016) <https://www.immigration.govt.nz/documents/amendmentcirculars/amendment-circular-2016-03.pdf $>$.

127 Michael Woodhouse and Anne Tolley, 'Changes Put Kiwis First in Line for Jobs' (Media Release, 12 April 2016).

128 Department of Home Affairs, Labour Agreement Program Information Guide (2018) 4, 7.

129 OECD, 'International Migration Outlook: SOPEMI 2009' (Multilingual Summary, OECD Publishing, 2009) <https://www.oecd.org/migration/mig/43176823.pdf>; John Azarias et al, 'Robust New Foundations: A Streamlined, Transparent and Responsive System for the 457 Programme: An Independent Review into Integrity in the Subclass 457 Programme' (Review, September 2014); Chris F Wright and Andreea Constantin, 'Inquiry into the Impact of Australia's Temporary Work Visa Programs 
degrees, on employer attestation to prove a need for frontline migrant care workers. The simplistic notion that employers will only go to the trouble and expense of employing a migrant worker when they want to meet a shortage skims over a range of motives an employer may have for using a migrant worker. These could be a reluctance to invest in training for existing or prospective staff, a desire to move towards a de-unionised workforce or, for a (perhaps small) minority of employers, a belief that it is easier to avoid paying minimum wage rates and conditions for temporary migrant workers. ${ }^{130}$ For other employers, there is a perception that they gain a cost advantage, either directly or indirectly, because temporary migrant workers will be willing to work for less or be more productive by working harder for the same pay. ${ }^{131}$ To varying degrees, both Australia and New Zealand rely on employer attestation coupled with verification by a government agency (in New Zealand, Work and Income) or department (in Australia, Department of Jobs and Small Business) to confirm the need for migrant labour. An independent review of the Australian 457 visa programme proposed that Australia adopt an independent labour market testing model and an earlier review suggested the compilation of shortage lists with regional nuances depending on labour market needs in different locations. ${ }^{132}$ Australia, it appears, is developing a more rigorous compilation of occupational shortage lists with the abolition of the 457 visa. Occupations eligible for its replacement, the TSS visa, are now reviewed regularly by the Department of Jobs and Small Business to ensure their responsiveness to changes in the Australian labour market. Regional variances are now taken into account with the development of a new interim Regional Occupations List. Other countries have adopted a different regulatory framework for ascertaining skill shortages. ${ }^{133}$ For example, in the UK, an independent body, the Migration Advisory Committee ('MAC'), provides recommendations to government regarding the composition of the occupations eligible for migration. The MAC has previously recommended that the government not add care occupations to the shortage list because there needed to be a greater public investment in the sector so as to increase wages and conditions to make jobs more attractive to locals and a reconsideration of the onerous education requirements for local workers seeking a care qualification. ${ }^{134}$ The MAC's approach adverts to the

on the Australian Labour Market and on the Temporary Work Visa Holders' (Submission 23, Senate Education and Employment References Committee, 1 May 2015).

130 Howe, 'Is the Net Cast Too Wide', above n 32, 460-1.

131 Robert MacKenzie and Chris Forde, 'The Rhetoric of the "Good Worker" Versus the Realities of Employers' Use and the Experiences of Migrant Workers' (2009) 23 Work, Employment and Society 142; Elaine Moriarty et al, “Taking on Almost Everyone?" Migrant and Employer Recruitment Strategies in a Booming Labour Market' (2012) 23 International Journal of Human Resource Management 1871; Roger Waldinger and Michael I Lichter, How the Other Half Works: Immigration and the Social Organization of Labor (University of California Press, 2003) 160-3.

132 Azarias et al, above n 129; Deegan Report, above n 66.

133 Howe, 'Does Australia Need an Expert Commission to Assist with Managing its Labour Migration Program?', above n 102. See also the special issue of the journal Migration Letters dedicated to this topic: Philip Martin and Eugen Stark (eds), 'Expert Commissions and Migration Policy Making' (2014) 11(1) Migration Letters.

134 Migration Advisory Committee, 'Skilled Shortage Sensible: First Review of the Recommended Shortage Occupation Lists for the UK and Scotland: Spring 2009' (Review, April 2009) 96. 
inherent difficulties and nuances in applying the concepts of 'skill' and 'shortage' to a particular sector. ${ }^{135}$

To conclude, Australia and New Zealand have designed front door and side door labour migration arrangements that require employers to attest to the need for frontline care workers from overseas, with varying degrees of oversight by government departments. In both countries employer requests are not verified via independent labour market testing and reflect a demand-driven approach to labour migration which can produce adverse effects for both local and migrant workers, a subject to which we now turn.

\section{B Frontline Care Workers and the Conditions of Work in the Care Sector}

This part explores how the reliance on employer attestation of Australia and New Zealand's front and side doors adversely affects both local workers and overseas workers involved in frontline care work.

The ability of the care sector to attract and retain local workers is relevant to the question of whether frontline care occupations should be eligible for labour migration. In both Australia and New Zealand employers have reported challenges in attracting and retaining local workers in lower-skilled jobs in the care sector. On the one hand, this could be explained by the fact that care work is inherently difficult - physically demanding, repetitive, low status and often involving the performance of what are often viewed as dirty or demeaning tasks. ${ }^{136}$ However, on the other hand, high turnover could be attributed to poor management practices in the sector, limited career pathways and opportunities for development and training, underemployment, as well as depressed wages. ${ }^{137}$ Although the extent to which the latter can be addressed is constrained by public budgets and commercial pressures in the sector, there needs to be greater investigation of the former to address the turnover issue. Neither New Zealand's approach of creating a dedicated front door temporary migration pathway for 'low-skilled' care workers nor Australia's de facto approach of opening up migration side doors and back doors through various non-dedicated programs, is likely to produce a sustainable and permanent frontline care workforce.

This short-term approach to frontline care migration will achieve one of two outcomes, both of which limit the ability of care workers (either local or migrant) to remain in the sector. One possibility is that it will embed the presence of migrant workers in care jobs designated as low-skilled and reduce pressure on employers to address the root causes of poor attraction and retention of local workers. This will not ameliorate wages and conditions in the sector and will mean that local workers may be priced out of frontline care jobs. A number of scholars have observed the ability of temporary migrant worker programmes to produce

135 A list of MAC publications is available at: Migration Advisory Committee, Publications, GOV.UK $<$ https://www.gov.uk/government/publications?departments $\% 5 \mathrm{~B} \% 5 \mathrm{D}=$ migration-advisory-committee $>$.

136 On the view that aged care work is 'dirty' work, see Siobhan Austen et al, 'Recognition: Applications in Aged Care Work' (2016) 40 Cambridge Journal of Economics 1037, 1050-1.

137 New Zealand Human Rights Commission, above n 49; Senate Community Affairs References Committee, 'Future of Australia's Aged Care Sector Workforce' (Report, Parliament of Australia, June 2017) ch 3 . 
permanent labour shortages because of the impact that increasing labour supply has on decreasing wages and conditions for a particular job. ${ }^{138}$ Costello argues that 'temporary status ... creates permanent demand' because temporary migrant workers are more willing to accept lower wages and conditions as their right to remain in the country of destination is contingent upon them being employed, whereas local workers have no such inducement. ${ }^{139}$ Ruhs claims there is a risk that if not managed properly, demand driven labour immigration programs can potentially create labour market distortions by inducing employers to develop structural preferences for migrant labour in ways that erode local job opportunities. ${ }^{140}$ A second possibility is that migrant workers themselves will choose to work in another occupation and industry if that opportunity arises and if wages and conditions do not improve in the care sector. Once temporary migrant workers receive permanent status they may become more selective about whether to stay in an occupation. Migrant workers may use a care job as a pathway to permanency but once this has been achieved, if the conditions and wages in the sector are not sufficient to hold workers in the sector, then these workers are likely to seek jobs elsewhere. This may well lead to increasing reliance on a temporary migrant workforce in the care sector as workers' temporary status allows the government to control in which occupations temporary migrant workers are employed. This has been the approach in New Zealand via the ESP and in Australia via labour agreements, both of which provide no clear pathway to permanent residency, which is why these doors have been depicted as 'trapdoors' in this article.

A related issue is the impact on job opportunities for local workers when temporary migrant workers are imported to meet what are seen as the low-skilled labour needs of employers. Although there is some evidence to show there are clear economic benefits to high-skilled labour migration programs for the local workforce and for national economic growth more generally, ${ }^{141}$ it is unclear whether 'low-skilled' labour migration is as effective in delivering economic benefits when it involves low wage sectors employing visa holders with less specialised skills. ${ }^{142}$ Boucher argues for greater scrutiny of the findings of economists that immigration has benign effects on the Australia labour market. Boucher also argues that more research on the relationship between immigration and youth unemployment is needed, particularly in light of the recent growth of

138 See, eg, Andrew Geddes and Sam Scott, 'UK Food Businesses' Reliance on Low-Wage Migrant Labour: A Case of Choice or Constraint?' in Martin Ruhs and Bridget Anderson (eds), Who Needs Migrant Workers?: Labour Shortages, Immigration, and Public Policy (Oxford University Press, 2010); Valeria Ottonelli and Tiziana Torresi, 'Inclusivist Egalitarian Liberalism and Temporary Migration: A Dilemma' (2012) 20 Journal of Political Philosophy 202.

139 Cathyrn Costello, 'Migrants and Forced Labour: A Labour Law Response' in Alan Bogg et al (eds), The Autonomy of Labour Law (Hart Publishing, 2015) 189, 210-11.

140 Martin Ruhs, The Price of Rights: Regulating International Labor Migration (Princeton University Press, 2013) 199-200.

141 See, eg, Susanne Bahn, 'Workers on 457 Visas: Evidence from the Western Australian Resources Sector' (2013) 39 Australian Bulletin of Labour 34, 54.

142 See, eg, Martina Boese et al, 'Temporary Migrant Nurses in Australia: Sites and Sources of Precariousness' (2013) 24 Economic and Labour Relations Review 316. 
temporary migrants in what is designated as low-skilled employment. ${ }^{143}$ According to a recent report by the Australian Productivity Commission there are some indications that migrants in these lower-skilled occupations may be displacing young local workers concentrated in low-skilled employment. ${ }^{144}$ Entry level, nonseasonal jobs in the labour market are important for local workers with limited skill sets or little to no paid work experience. A recent report found that there is increasing competition for low-skilled job vacancies in Australia with only one job advertised for every five low-skilled job seekers. ${ }^{145}$ The care sector provides a way of giving job opportunities to local job seekers in Australia and New Zealand without professional level skills and it is important that systemic issues around retention and attraction are dealt with prior to expanding temporary labour migration pathways. At present, the aged care sector has not been highly attractive to young Australians because this work is seen as low paid and low status characterised by underemployment and fragmented hours. ${ }^{146}$ The increasing reliance on migrant workers to meet frontline care vacancies is likely to embed this situation even further.

A final set of concerns relates to the protection from exploitation of temporary migrant workers employed in frontline care work. The different regulatory frameworks in New Zealand and Australia provide for varying degrees of oversight of the employment relationships of temporary migrant workers. For example, New Zealand's dedicated labour migration program means that the Department of Immigration is aware of how many visa holders under the Essential Skills Policy are employed in 'low-skilled' jobs in the care sector. This is because the ESP is reliant on an employer-sponsorship model (similar to Australia's TSS visa) so any employer who engages a temporary migrant worker is required to have applied for this privilege to the Department of Immigration. Because the ESP is a front door arrangement, the government is better placed to identify the profile of employers who employ temporary migrant workers and to monitor their use of the program and the employment conditions of visa holders. Often front doors are subject to a greater degree of regulation around their operation, with recent reforms in Australia and New Zealand seeking to strengthen the compliance regime for employers involved in the 457 visa/TSS visa and the ESP respectively. ${ }^{147}$ In contrast, in Australia where international students and working holiday makers are employed in frontline care jobs, the Department of Home Affairs is unable to ascertain the identity of their employers and the nature of their employment. This

143 Boucher, 'Australia's De Facto Low Skilled Migration Programs', above n 19.

144 Productivity Commission, above n 80, 9-11. See also Peter McDonald and Jeromey Temple, 'Immigration, Labour Supply and Per Capita Gross Domestic Product: Australia 2010-2050' (Final Report, Australian Demographic and Social Research Institute, May 2010)

$<$ https://www.homeaffairs.gov.au/research-and-stats/files/labour-supply-gdp-2010-2050.pdf>.

145 Anglicare Australia, above n 83, 21.

146 Senate Community Affairs References Committee, above n 137.

147 For example, in New Zealand's case, see the Immigration Amendment Act 2015 (NZ), which amended the Immigration Act 2009 (NZ) to strengthen the compliance regime and provide greater protection against migrant exploitation in the labour market. In Australia's case, see two recent legislative attempts to limit migrant worker exploitation under the 457 visa scheme: Migration Amendment Worker Protection Act 2008 (Cth) and Migration Amendment (Temporary Sponsored Visas) Act 2013 (Cth). 
presents challenges for monitoring and enforcing the workplace rights of these visa holders. A growing body of literature in Australia establishes the extremely vulnerable position of working holiday makers and international students in the Australian labour market because of their use of a visa for a non-work purpose. ${ }^{148}$ Nonetheless, front door labour migration programs like the ESP (or side doors like Australia's labour agreements stream for frontline care workers) are not without challenge. A key drawback of the employer-sponsorship model upon which these dedicated labour migration programs are based is that the visa holder has limited freedom of movement (or in some cases none at all) in the labour market. Because their visa is reliant on employer-sponsorship, the visa holder is constrained from choosing another employer as being without an employer-sponsor will lead to deportation. This vulnerability was identified in the New Zealand Human Rights Commission inquiry into aged care which found that migrant carers often work with shorter contracts, more irregular hours, for lower pay and in lower classified functions than local-born carers. ${ }^{149}$ This report also refers to the unions' claim that carers can sometimes be threatened with the withholding of their work permits in order for employers to gain compliance around working conditions. ${ }^{150}$

This vulnerability of temporary migrant workers, particularly in the care sector, is well documented in many international studies that suggest employer non-compliance with minimum labour standards in social care is exacerbated by workers' migrant status, particularly temporary status. ${ }^{151}$ In the Australian context, findings from research on compliance with employment law in service industries, such as hospitality, retail and cleaning, point to normative workplace cultures that permeate particular industries where employer non-compliance is 'structural' 152 and the normal way of 'doing business'. This can have particularly dire effects when it is played out in the migrant context. ${ }^{153}$ While to date there have been no published studies of care sector employer compliance with employment law in Australia, the Australian experience with structural non-compliance in low wage service industries and the New Zealand experience with migrant aged care workers, suggests that migrant care workers may be particularly susceptible to employer exploitation. The report of the New Zealand Human Rights Commission inquiry into aged care acknowledged the varied provenance of migrant care workers, concluding that '[w]hile many migrant workers in aged care are respectfully employed and supported by the older people they care for, others are

148 See, eg, Reilly, 'Protecting Vulnerable Workers', above n 122; Laurie Berg, Migrant Rights at Work: Law's Precariousness at the Intersection of Immigration and Labour (Routledge, 2016); Anthony Forsyth, 'Victorian Inquiry into the Labour Hire Industry and Insecure Work' (Final Report, 31 August 2016).

149 New Zealand Human Rights Commission, above n 49, 103.

150 Ibid 107.

151 See, eg, Margriet Kraamwinkel, 'Organizing in the Shadows: Domestic Workers in the Netherlands' (2016) 17 Theoretical Inquiries in Law 351; Shereen Hussein, Submission to King's College London, Baroness Kingsmill Parliamentary Review, 20 February 2014; Alessio Cangiano et al, 'Migrant Care Workers in Ageing Societies: Research Findings in the United Kingdom' (Report, COMPAS, University of Oxford, June 2009) 135-43.

152 Tham, Campbell and Boese, above n 33.

153 Ibid. 
working too hard, for too long and for too little, and have no public way in which they can air their concerns'. ${ }^{154}$ A key part of the report focused on the tied nature of the work permit under the Essential Skills Policy with the ability of migrant care workers to report exploitative treatment or even change employers, completely constrained by the need to maintain their employment relationship in order to remain in New Zealand. Costello characterises this as an additional layer of dependence, created by the tie of migration status to employment within employersponsored visa schemes, ${ }^{155}$ which intensifies the inherently unequal nature of employment relationships. ${ }^{156}$

Additionally, both countries' migration pathways for frontline care workers are essentially a 'trapdoor', which render it acutely difficult for these workers to transition to permanent residency. Care workers in Australia under a labour agreement or on visas for Pacific workers are in effect 'permanently temporary' in that they cannot apply for permanent residency, yet they work and reside over a long period in a country other than their home, establishing new ties, connections and roots without any of the rights and entitlements which derive from membership of a state. This is also true of New Zealand's frontline migrant care workers on the ESP. Reilly challenges this approach to migration policy, arguing that there are ethical limits to temporary work because "the vulnerability of migrant workers is inherent in their migration status' ${ }^{157} \mathrm{He}$ argues that the only way for states to remove the systemic precarity of temporary migrant workers is to address the membership of migrant workers as a condition of their working and living in the state. From the perspective of those being cared for, the temporary nature of migrant care work is also regarded as less desirable, creating precarity not just for the worker but also for service users. Callister, Didham and Badkar criticise this regulatory approach for failing to prioritise the needs of service users and by creating an inbuilt instability in the provision of care. ${ }^{158}$

If wages and conditions for frontline care workers do not improve, it is unlikely that policymakers will remove this 'trapdoor' because if these workers receive permanent residency they will have the opportunity to move to sectors in the labour market with better remuneration and working conditions. Permanent residency means they are no longer required to be employed in frontline care work as they are no longer dependent on a temporary work visa tied to an occupation in a particular sector or industry.

154 New Zealand Human Rights Commission, above n 49, 110.

155 Cathyrn Costello, above n 139.

156 See, eg, Mark Freedland and Nicola Kountouris, The Legal Construction of Personal Work Relations (Oxford University Press, 2011).

157 Alexander Reilly, 'The Membership of Migrant Workers and the Ethical Limits of Exclusion' in Joanna Howe and Rosemary Owens (eds), Temporary Labour Migration in the Global Era (Hart Publishing, 2016) 277, 279.

158 Callister, Didham and Badkar, above n 30. 


\section{CONCLUSION}

In both Australia and New Zealand labour migration pathways for frontline care workers are vexed and contingent. The mapping exercise undertaken in this article has exposed how the gendered framing of skill underpins the migration regulation of Australia and New Zealand. In both jurisdictions, because frontline care work is designated as low-skilled work, it is managed through a series of front, side and back door arrangements which restrict the ability of frontline care workers to transition to permanent residency. We depict this situation as a 'trapdoor' ensnaring visa holders in precarious, temporary work. Although New Zealand's ESP provides a 'front door' for migrant care workers, these workers face significant challenges transitioning to permanent residency because their visas expire each year. This produces an inherent vulnerability for these workers in the New Zealand labour market as they are continually dependent upon employer sponsorship for their ability to remain in New Zealand. Although Australia has no direct labour migration pathway for migrant care workers, the DAMA and labour agreements stream provide a 'side door' that incorporates greater labour market protection of frontline care workers as this is seen as vulnerable work. However, as in New Zealand, these visas are still underpinned by a principle of employer sponsorship and are time bound, producing additional vulnerability for these workers in the labour market. In both countries, international students and backpackers are a 'back door' source of frontline care workers, although it is likely these are used more heavily to meet labour needs in the Australian labour market given that New Zealand's ESP provides employers with an alternative and more direct way to recruit these workers.

Each of the current temporary migration pathways identified in this article produce a frontline migrant care workforce in Australia and New Zealand that is vulnerable to exploitation in the labour market and responds to perceived needs for more migrant care workers by producing a temporary workforce which fails to meet either the worker or industry's needs in the long term. In order to develop a sustainable frontline care workforce it is important that there is not an over reliance on a revolving door of permanently temporary migrant workers. Instead, there should be independent and robust assessment of the labour market need for migrant frontline care workers. There also needs to be government and industry investment in the training of local frontline care workers; and strategies to improve their attraction and retention in the sector through improvements in the wages and conditions of all frontline care workers, regardless of whether they are Australianborn or a permanent or temporary migrant. 